\title{
Application of the Hess-Brezowsky classification to the identification of weather patterns causing heavy winter rainfall in Brittany (France)
}

\author{
O. Planchon, H. Quénol, N. Dupont, and S. Corgne \\ COSTEL Laboratory, LETG - UMR 6554 CNRS, Rennes-2 University, Place Recteur Henri le Moal, \\ 35043 Rennes Cedex, France
}

Received: 5 November 2008 - Revised: 15 April 2009 - Accepted: 7 July 2009 - Published: 17 July 2009

\begin{abstract}
An accurate knowledge of the weather patterns causing winter rainfall over the Scorff watershed in western Brittany (W. France) was developed prior to studies of the impact of the climate factor on land use management, and of the hydrological reponses to rain-producing weather patterns. These two studies are carried out in the context of the climate change. The identification of rainy air-circulation types was realized using the objective computational version of the 29-type Hess and Brezowsky Grosswetterlagen system of classifying European synoptic regimes, for the cold season (November-March) of the 1958-2005 period at the reference weather station of Lorient, and 13 other stations located in western and southern Brittany, including a more detailed study for the wet 2000-2001 cold season for three reference stations of the Scorff watershed (Lorient, Plouay and Plouray). The precipitation proportion (including the days with rainfall $\geq 20 \mathrm{~mm}$ ) was calculated by major aircirculation type (GWT: see Appendix A) and by individual air-circulation subtype (GWL: see Appendix A) for the studied time-period. The most frequently occurrence of rainy days associated with westerly and southerly GWL confirmed well-known observations in western Europe and so justify the use of the Hess-Brezowsky classification in other areas outside Central Europe. The southern or south-western exposure of the watershed with a hilly inland area enhanced the heavy rainfall generated by the SW and S circulation types, and increased the difference between the rainfall amounts of coastal and inland stations during the wettest days.
\end{abstract}

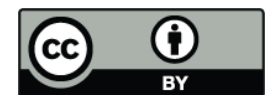

Correspondence to: O. Planchon (olivier.planchon@uhb.fr)

\section{Introduction}

Heavier precipitation in winter is the distinctive feature of the most seasonal-contrasted regimes affecting the European Atlantic coastal fringe, including western France. The interanual variability of precipitation and its hydrological impacts, especially the increase in winter precipitation and river flow already observed since the middle of the 1970s in maritime areas of Atlantic Europe, is monitored in the context of the climate change (European Environment Agency, 2008). A winter rainfall increase was recorded in western Europe since the middle of the 1970s: in the British Isles (Mayes, 1996; Kiely, 1999), in western France (Dubreuil et al., 1996; Dupont et al., 2000). This increase of winter rainfall was connected to a higher frequency of westerlies over Europe (Bárdossy and Caspary, 1990) and an increasing number of midlatitude cyclones over the North-West of Europe during the second half of the 20th century (Bartholy et al., 2006). Werner et al. (2000) and Kyselý and Huth (2006) quoted an increase in the mean life-time of zonal circulation in winter during the 1990s, using the Hess-Brezowsky classification. Klein tank and Können (2003), and Moberg and Jones (2005) found trends in winter mean as well as strong rainfall events over parts of Europe, and recent studies show that winter precipitation became more intense in the United Kingdom during the last 100 years (Maraun et al., 2008).

The anthropogenic planning and activities are often accused after each hydrological event which causes serious damages. In intensive agricultural regions like Brittany, for several years before, short-term land use and cover changes represent an important key indicator of water transfer processes (Cheverry, 1998). North-Western France is subjected to strong land use and land cover changes for the second half

Published by Copernicus Publications on behalf of the European Geosciences Union. 
of the twentieth century. These changes in farming practices and the urban expansion (in the Scorff Watershed, especially around the Lorient agglomeration) involved varied and heterogeneous surface condition changes on catchments. The river risings, especially in the catchments with an impermeable substratum, could be enhanced by these changes of surface condition (Moussa et al., 2001; Carluer and De Marsily, 2004), but it is connected to climatic features too (Dupont et al., 2000). The countryside with many hedges, trees and small fields (bocage) was preserved in western Brittany, but the presence of fields with no or little vegetation during rainy winters increases pollutant fluxes (nitrogen, pesticide...) towards the rivers. The Scorff watershed, located in western Brittany, is subjected to a typical temperate oceanic precipitation regime with spatial variations that can locally influence the land cover implantation. An accurate assessment of the space-time variation of the winter vegetation cover is then essential for controlling land management and helping in local decision making. Local managers especially focussed on land use and land cover during winter because it represents an intermediary period for main crops in this region. The climate impact on the Scorff watershed, and comparatively to western and southern Brittany, was first analysed through the study of the rainfall space-time variability during the November-March 1958-2005 period (identified with the "cold season"). For accurate knowledge of weather patterns causing rainfall and especially heavy rainfall (precipitation $\geq 20 \mathrm{~mm}$ ), the Hess-Brezowsky classification of circulation patterns was applied to the November-March 1958-2005 period, including a more detailed analysis for the wet cold season of 2000-2001. Precipitation amounts and percentages were calculated by major air-circulation type (GWT: see Appendix A) and by individual air-circulation subtype (GWL: see Appendix A) for the selected weather stations of western and southern Brittany, in order to identify the rainiest circulation types during the cold season. This paper follows previous results obtained using the subjective (Quénol et al., 2008) and objective (Planchon et al., 2008) method of HessBrezowsky. Preliminary works including land use and land cover changes studies (Corgne et al., 2002, 2007) were developed between 2000 and 2006 within the framework of a research contract supported by the Scorff Watershed Association about the water quality monitoring (as part of the Bretagne Eau Pure program). These works are now carried out within the framework of:

1. the CLIMASTER co-supported research program (INRA and administrations of four regions in western France) about "climatic change, agricultural systems, natural resources and territorial development", http://www.rennes.inra.fr/climaster/;

2. the RICLIM-CNRS 2663 multidisciplinary Research Group "Climate Risks", http://www.uhb.fr/sc_sociales/ riclim/;
3. the research program about "Air-mass dynamics and climate risks", supported by the MAIF Foundation.

This application of the Hess-Brezowsky classification is a first test of the validity of the method in western France. The Hess-Brezowsky classification allows researches on longterm climatological data series, because the daily Objective Grosswetterlagen Catalogue is available since 1850. This long period of observation is essential for studies on climate change.

\section{The study area and its prevailing climatic features}

\subsection{Site description}

The Scorff watershed represents for local managers an important environmental stake since it provides drinking water for eighty thousand people. The Scorff watershed is one of the "Bretagne Eau Pure" experimental watersheds of Brittany (2000-2006), which is now studied within the framework of the GEPMO regional program about organic pollutants and water quality control (http://www.bretagne-environnement.org/membres/ matiere-organique/index.php/). The study area is a catchment area of $482 \mathrm{~km}^{2}$ located on the south-western coast of Brittany (France) and with a maximum altitude of $280 \mathrm{~m}$ on its northernmost edge. The Scorff watershed is characterized by a relatively intensive farming combined with wet and warm autumns and winters that produce significant amounts of nitrogen before winter infiltration of water (Cheverry, 1998). For several years, local managers point out a relative degradation of water quality (nitrogen, pesticides, phosphor...) that necessitate a fine monitoring of the land cover evolution on the watershed.

\subsection{Large scale rainy weather patterns and impacts on climatic features in Brittany}

Heavier precipitation during the cold season is the distinctive feature of the most seasonal-contrasted regimes affecting the Atlantic coastal fringe of Europe, including Brittany (Wallén, 1970; Barry and Chorley, 1987). Because of the seasonal oscillation of the frequency and intensity of the Atlantic weather disturbances the rainiest westerly and southwesterly atmospheric circulations occur especially in autumn and winter (Trzpit, 1978; Pagney, 1988). The strongest westerlies occurring at the beginning of winter (December and January) induce heavy precipitation on the European Atlantic fringe; December and January are the two rainiest months in western Brittany. At small scales, topographical effects influence the effect of the circulation type on precipitation. The highest hills of Brittany reach about $380 \mathrm{~m}$ and precipitation is orographically enhanced on hillslopes presenting a westerly/southwesterly/southerly aspect. The mean annual 
Table 1. Geographical coordinates of the selected weather stations. IN: Identification number (see Fig. 1).

\begin{tabular}{clrccc}
\hline IN & Station & Latitude $(\mathrm{N})$ & Longitude $(\mathrm{W})$ & Altitude $(\mathrm{m})$ & ${\text { Dist./coast }(\mathrm{km})^{\mathrm{a}}}^{\mathrm{a}}$ \\
\hline 1 & AURAY & $47^{\circ} 40^{\prime}$ & $02^{\circ} 58^{\prime}$ & 26 & 9 \\
2 & BREST & $48^{\circ} 27^{\prime}$ & $04^{\circ} 25^{\prime}$ & 94 & 8 \\
3 & CORAY & $48^{\circ} 03^{\prime}$ & $03^{\circ} 50^{\prime}$ & 231 & 20 \\
4 & LORIENT & $47^{\circ} 46^{\prime}$ & $03^{\circ} 27^{\prime}$ & 42 & 5 \\
5 & PENMARC'H & $47^{\circ} 48^{\prime}$ & $04^{\circ} 22^{\prime}$ & 3 & 0 \\
6 & PLOERMEL & $47^{\circ} 57^{\prime}$ & $02^{\circ} 24^{\prime}$ & 65 & 46 \\
7 & PLOUAY & $47^{\circ} 54^{\prime}$ & $03^{\circ} 20^{\prime}$ & 74 & 22 \\
8 & PLOURAY & $48^{\circ} 07^{\prime}$ & $03^{\circ} 26^{\prime}$ & 205 & 44 \\
9 & PONTIVY & $48^{\circ} 04^{\prime}$ & $02^{\circ} 57^{\prime}$ & 83 & 48 \\
10 & QUIMPERLE & $47^{\circ} 52^{\prime}$ & $03^{\circ} 33^{\prime}$ & 25 & 11 \\
11 & QUIMPER & $47^{\circ} 58^{\prime}$ & $04^{\circ} 10^{\prime}$ & 90 & 12 \\
12 & Pointe du RAZ & $48^{\circ} 02^{\prime}$ & $04^{\circ} 44^{\prime}$ & 67 & 0 \\
13 & RENNES & $48^{\circ} 04^{\prime}$ & $01^{\circ} 44^{\prime}$ & 36 & 84 \\
14 & ROSTRENEN & $48^{\circ} 14^{\prime}$ & $03^{\circ} 18^{\prime}$ & 262 & 54 \\
\hline
\end{tabular}

a Distance from west or south coast of Brittany.

precipitation is less than $800 \mathrm{~mm}$ on the coast (south of Lorient), but is estimated at more than $1200 \mathrm{~mm}$ in the Black Mountains area (Kessler and Chambraud, 1986; Lebourgeois et al., 2006). Unfortunately there is no weather station on the highest hills $(326 \mathrm{~m})$.

\section{Data and methodology}

\subsection{Meteorological data}

The climatic data used in this study is the daily precipitation recorded during the 1958-2005 period at selected reference weather stations located in western and southern Brittany, including three available reference stations (Lorient, Plouay and Plouray: see Fig. 1b) located in the Scorff watershed. As the Scorff watershed is included in the regional network of the former "Bretagne Eau Pure" program and of the current GEPMO regional program, weather stations were selected in a wider area in western and southern Brittany.

Few precipitation data are available for the 1958-2005 in the Scorff watershed (Lorient and Plouay). The station of Plouray was opened in 1986, but this station was selected because of its location near the northernmost edge of the upper Scorff watershed. In the Scorff watershed area, the station of Lorient is the nearest of the Atlantic Ocean. The stations of Plouay and Plouray are located in the northern part of the Scorff watershed close to the Black Mountains.

These stations belong to the French national weather agency Météo-France (Climathèque database), with the exception of the daily rainfall of Rennes, gotten from the European Assessment \& Dataset (ECA\&D: http://eca.knmi.nl, Klein Tank et al., 2002). In the studied area, precipitation is recorded for the 1958-2005 period only at few stations. The stations listed in Table 1 were selected because of their pre- cipitation data series for the 1958-2005 period, with the exception of the station of Plouray. All data series are complete, with the exception of those of Auray and Pontivy. Missing values must be mentioned at the station of Auray before February 1960 and in December 1960 and at the station of Pontivy between November 1963 and February 1964. In addition to the 1958-2005 rainfall time series, the 1971-2000 normals was used as a reference to define the precipitation anomaly. Heavy rainfall was identified by daily precipitation $\geq 20 \mathrm{~mm}$. In North-Western France, the French national weather agency Météo-France and the SPC in Brittany (Service de Prévision des Crues/flood forecasting service) send flood alerts after daily rainfall of more than $20 \mathrm{~mm}$ during the cold season.

\subsection{The Hess-Brezowsky classification of circulation patterns}

Analysis of the space-time variability of precipitation and its impacts on floods must take the variety of disturbance track patterns into account. Such an analysis is possible using the Objective Grosswetterlagen Catalogue adapted from the Hess-Brezowsky classification of circulation patterns. The original (subjective) Hess-Brezowsky classification of largescale circulation patterns is frequently used to characterize the atmospheric flow and weather patterns over the eastern North Atlantic and Europe (Hess and Brezowsky, 1952; Gerstengarbe and Werner, 2005; Kyselý and Huth, 2006). Based on the mean air pressure distribution (sea level and $500 \mathrm{hPa}$ level) over the North Atlantic Ocean and Europe, the classification initially identifies three groups of circulation types (zonal, mixed and meridional), which are divided into 5 major types (Grosswettertypen, GWT: westerly circulation types, southerly circulation types, northwesterly and 


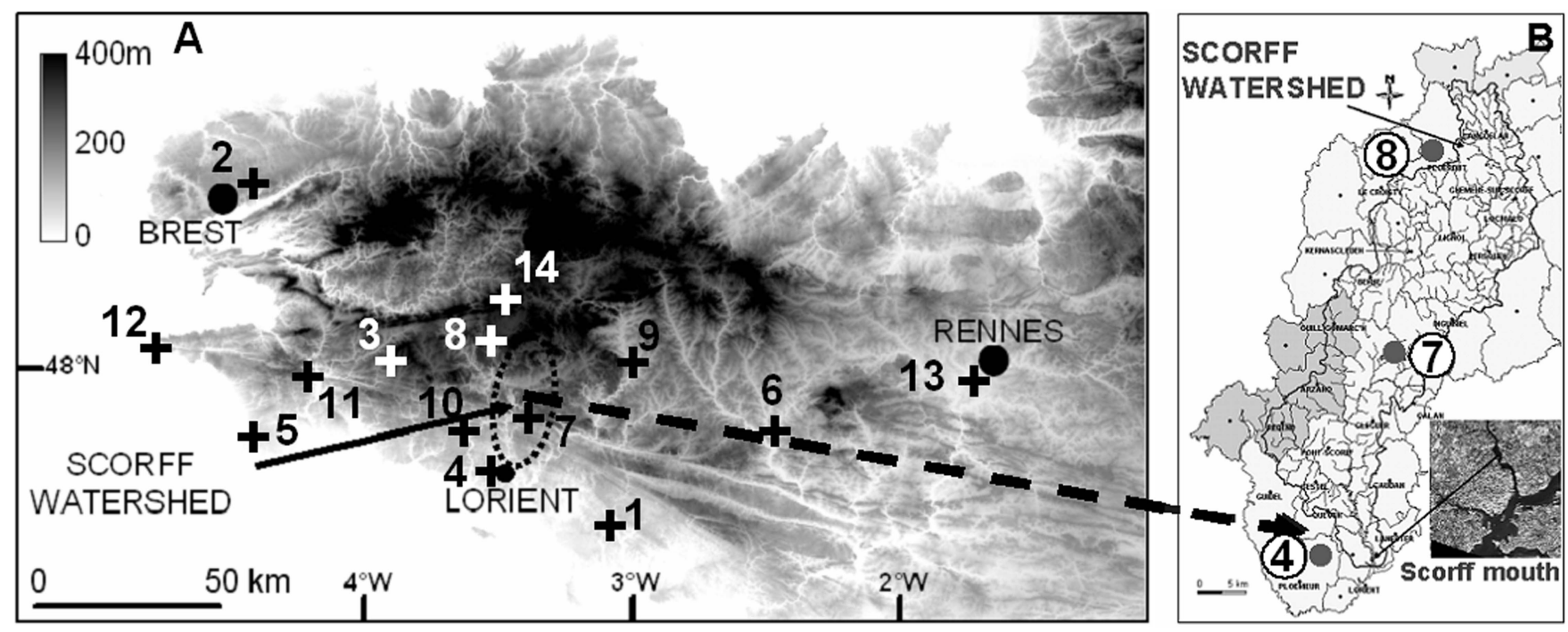

Fig. 1. Location of the studied area (Scorff watershed): (a) Location of the Scorff watershed and of all reference weather stations in Brittany. Station names associated with each identification number are specified in Table 1; the topographic map of Brittany is extracted from Global Land Cover Facility (www.landcover.org). (b) Detailed map of the Scorff watershed with the location of the reference weather stations (4: Lorient, 7: Plouay and 8: Plouray).

northerly circulation types, northeasterly and easterly circulation types, main high/low pressure area over Central Europe) and 29 subtypes (Grosswetterlagen, GWL). The list of GWT and GWL is given in Appendix A.

The Objective-GWL system is an objective computational version of the 29-type Hess and Brezowsky Grosswetterlagen system of classifying European synoptic regimes developed within the framework of the COST-733 international program (James, 2007; http://www.cost733.org). The Objective-GWL types have the same meaning and nomenclature as the original types and are also filtered so that the minimum allowed event duration is 3 days (as with Hess and Brezowsky). The primary differences to the original series are that the Objective-GWLs have a greater spatial coherence outside of Central Europe and the classification is homogeneous and consistent throughout the years. The HessBrezowsky classification has been used in various studies assessing trends in frequencies, changes in event duration, and transition probabilities between GWL types (Bárdossy and Caspary, 1990; Klaus, 1993), but has never applied to climatological studies in western France. This classification was mainly developed for the weather in Germany and neighbouring countries in Central Europe and there has never been an attempt to establish a similar alternative classification system for France. Therefore, an essential aim of this paper is to assess if the Hess-Brezowsky classification can be applied to Western Europe.

Analysis was carried out here by major type (GWT) and subtype (GWL) of circulation patterns. Frequencies for the GWT and GWL were calculated over the 1958-2005 period. Proportion of precipitation was calculated by GWT and GWL for the daily data series of the weather station of Lorient and each one of the 12 other selected stations in western and southern Brittany (see Fig. 1 and Table 1) over the 1958-2005 period. More detailed observations and analysis using the Hess-Brezowsky classification were made in order to study the connection between the GWT/GWL and the daily precipitation during the remarkable 2000-2001 wet cold season at the three stations of Lorient, Plouay and Plouray. The weather maps, which allowed to analyse the weather patterns associated with some selected heavy rainfall events, were adapted from the NCEP Reanalysis retrieved from http://www.wetterzentrale.de. The objective GWL catalogue was kindly sent by P. M. James.

\section{Results}

\subsection{Connections between precipitation and GWT: sea- sonal timescale study in western and southern Brit- tany}

The precipitation proportion at the weather stations of western and southern Brittany by GWT (Fig. 2) clearly confirms that a large part of precipitation is associated with the westerly and southerly circulation types during the cold season months, which include the more frequently rain-producing major circulation types throughout the year in Western Europe (westerly and southwesterly circulation patterns: Moron, 1990).

The prevailing winds in western-Atlantic Europe blow from the southwest quadrant (e.g. Barrow and Hulme, 1997) and studies on the linkage between circulation patterns and 


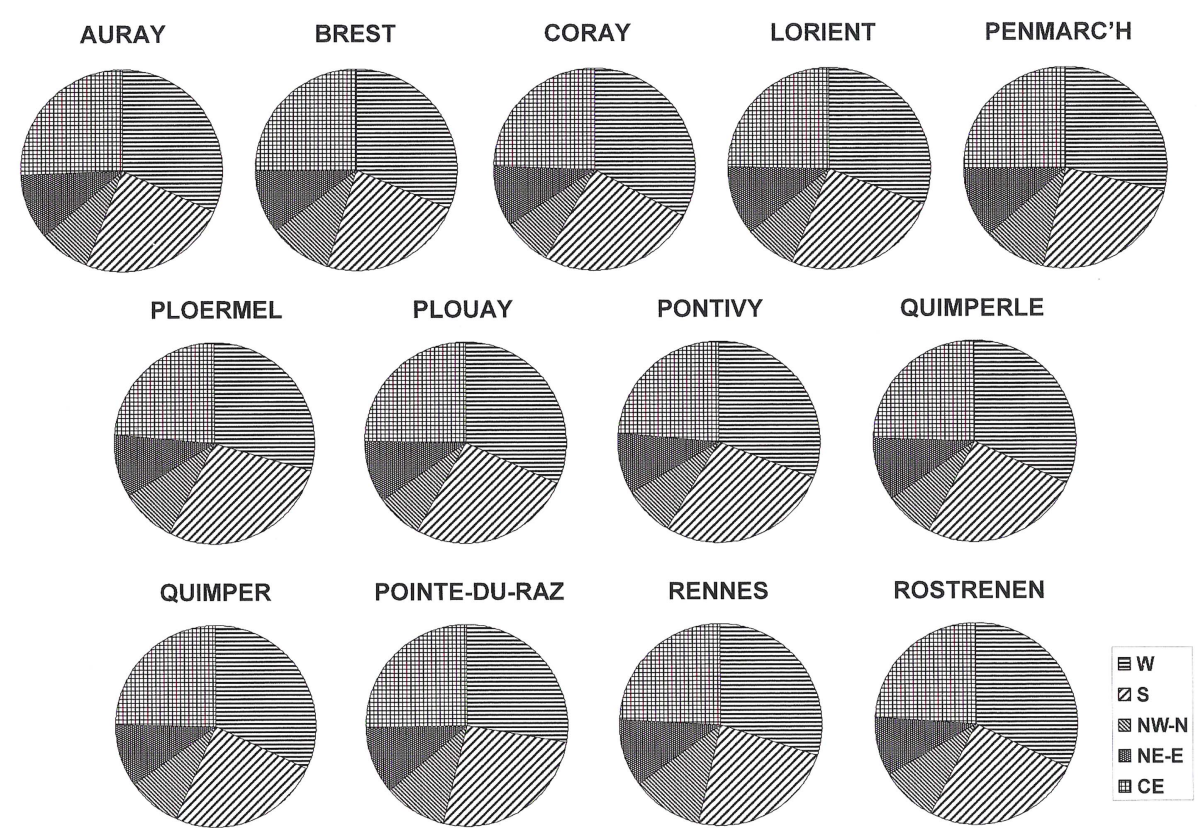

Fig. 2. Precipitation proportion at the reference stations in western and southern Brittany by Hess-Brezowsky GWT (November-March 1958-2005). W: westerly circulation types, S: southerly circulation types, NW-N: northwesterly and northerly circulation types, NE-E: northeasterly and easterly circulation types, CE: main high/low pressure area over Central Europe.

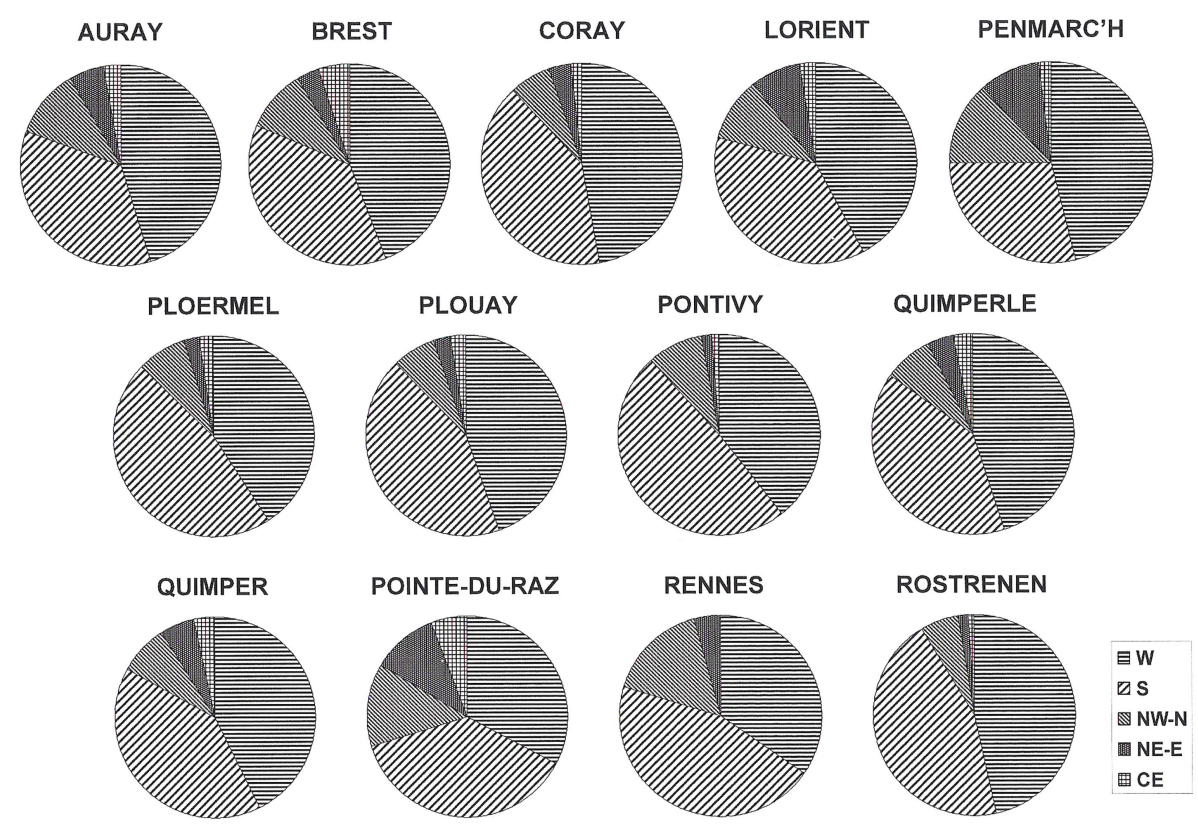

Fig. 3. Proportion of precipitation $\geq 20 \mathrm{~mm}$ at the reference stations in western and southern Brittany by Hess-Brezowsky GWT (NovemberMarch 1958-2005). W: westerly circulation types, S: southerly circulation types, NW-N: northwesterly and northerly circulation types, NE-E: northeasterly and easterly circulation types, CE: main high/low pressure area over Central Europe.

precipitation amounts showed that SW circulations produce the heaviest precipitation in different regions even in eastern France (Contat et al., 1965; Claval, 1972; Blanchet, 1981). The precipitation proportion associated with westerly and southerly circulations type, at the reference stations in Brittany, was included between 53.7\% (Penmarc'h) and
$58.6 \%$ (Pontivy) in 1958-2005; 56.2\% at Lorient. The rainproducing effect of the westerly and southerly circulation types over all Brittany explains this small range of precipitation proportion, and the non-existence of a spatial organization. 


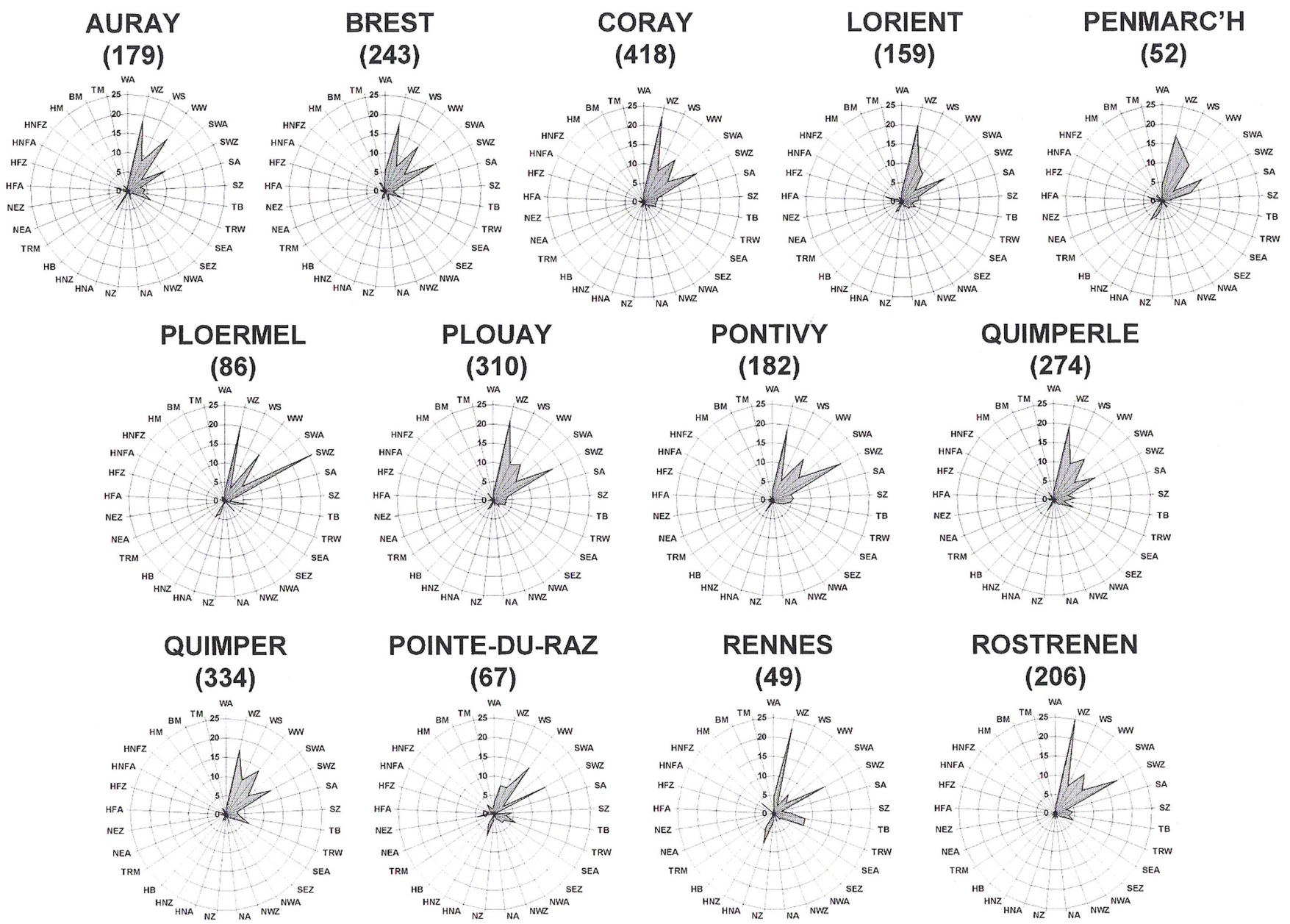

Fig. 4. Proportion of precipitation $\geq 20 \mathrm{~mm}$ at the reference stations in western and southern Brittany by Hess-Brezowsky GWL (NovemberMarch 1958-2005). W: westerly circulation types, S: southerly circulation types, NW-N: northwesterly and northerly circulation types, NE-E: northeasterly and easterly circulation types, CE: main high/low pressure area over Central Europe (with total number of days with precipitation $\geq 20 \mathrm{~mm}$ over all the period).

The proportion of daily precipitation $\geq 20 \mathrm{~mm}$ at the same weather stations in Brittany by GWT (Fig. 3) confirms the prevailing heavy rain-producing westerly and southerly circulation types during the cold season months in the studied area. However, the results shows some differences between the stations, due to their location and exposure to the rainproducing weather systems.

Most of the reference stations recorded between 80 and $91 \%$ of their heavy precipitation in association with westerly and southerly circulation types, with the exception of the less rainy coastal (Lorient: $79.2 \%$, Penmarc'h: $75 \%$, Pointe-duRaz: $70.1 \%$ ) or inland and sheltered (Rennes: $79.6 \%$ ) stations. Conversely, stations located in hilly areas facing west or south showed the highest proportion of heavy precipitation associated with the westerly and southerly circulation types, especially in the Black Mountains area and their low foothills towards the south and southwest (e.g. Rostrenen: $91.3 \%$, Coray: $88 \%$ ). The stations located in coastal and hilly areas (the most directly exposed to the cyclonic weather systems) were subjected to the highest proportion of heavy precipitation associated with westerly circulations (at least $44 \%$ ), which was higher than the proportion of heavy precipitation associated with southerly circulations. Located on a coastal plain facing south-west and south, the station of Lorient was subjected to the highest proportion of heavy precipitation associated with westerly circulation too, but the percentage was slightly lower $(42.1 \%)$. On the other hand, heavy precipitation was at first associated with southerly circulations at stations located in valleys and basins (relatively) sheltered from the westerly flow, e.g. Pontivy, Ploërmel and Rennes.

The analysis in 5 major types allows to show that precipitation and (more clearly) daily precipitation $\geq 20 \mathrm{~mm}$ in western and southern Brittany is generally associated with westerly and southerly circulation types, but each of these 5 groups includes anticyclonic and cyclonic situations. Thus, 

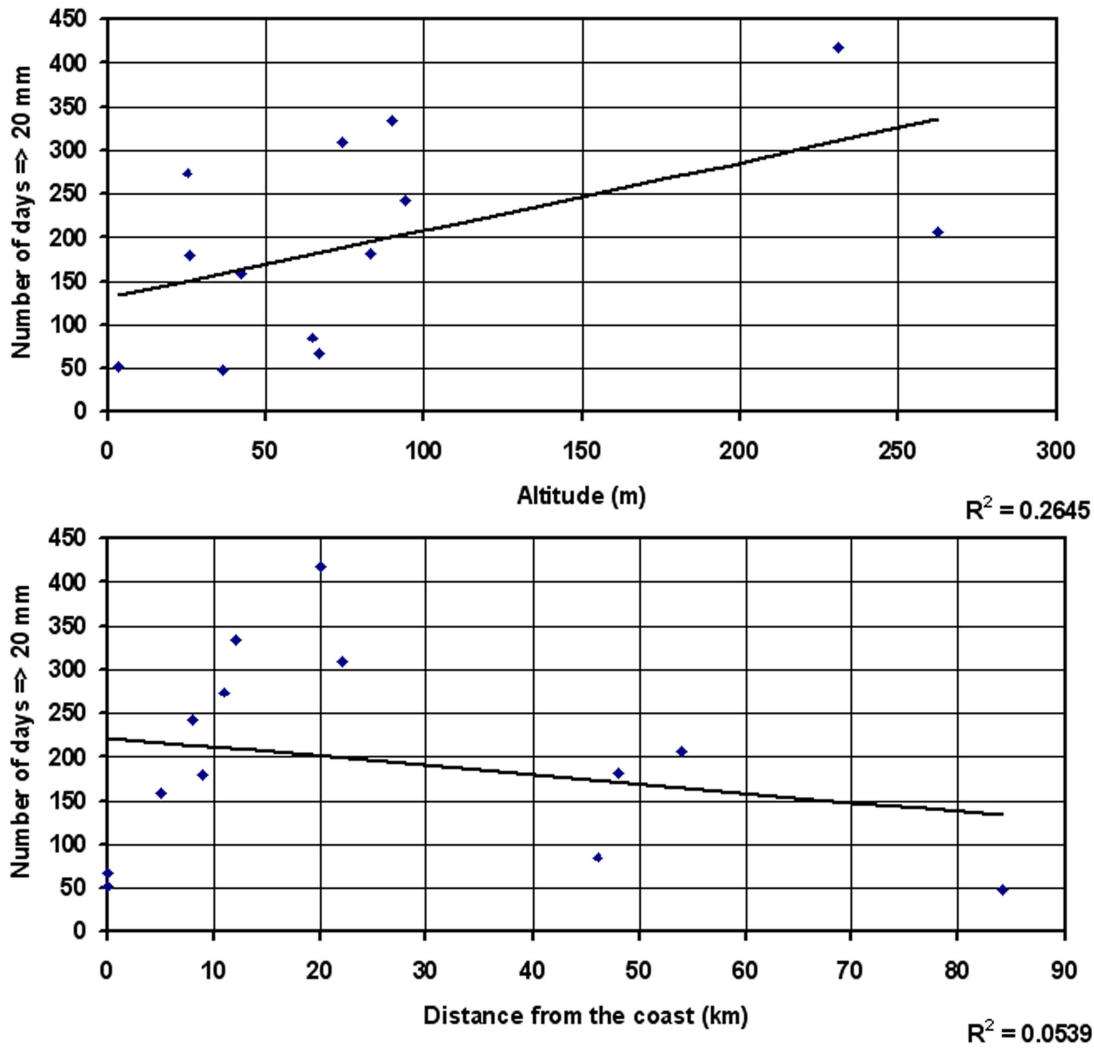

Fig. 5. Correlation between the altitude and the number of days with precipitation $\geq 20 \mathrm{~mm}$ (a) and between the distance from the west or south coast of Brittany and the number of days with precipitation $\geq 20 \mathrm{~mm}$ (b) for the reference stations in western and southern Brittany (November-March 1958-2005).

a similar analysis was carried out for the 29 GWL (see Appendix A) and for heavy precipitation for the whole available period (1958-2005) and using data of the same 13 reference weather stations, in order to point up some specific weather patterns for such rainfall events (Fig. 4).

For all stations, Fig. 4 shows that heavy precipitation was at first associated with the cyclonic westerly circulations (essentially WZ and WW and after WS) and secondarily with cyclonic meridional southerly circulations (SZ, TB and TRW). These results clearly confirms the results obtained by Moron over Europe (1990) with an other statistical method of classification of weather patterns (for the 1979-1988 period only). These more precise and detailed results must take the number of days with heavy precipitation by station into account. The less rainy stations located on the capes exposed to the prevailing winds (Penmarc'h, and Pointe-du-Raz) and in the inland sheltered basins (Rennes and Ploërmel) recorded the lowest number of precipitation $\geq 20 \mathrm{~mm}$ (less than 100 days), while stations located south and south-west of the Black Mountains (Coray, Plouay, Quimper) recorded more than 300 days with heavy precipitation. Although stations with extreme (low or high) number of days with heavy precipitation were associated with the topographical features above-mentioned, there are no significant correlation between the number of days with precipitation $\geq 20 \mathrm{~mm}$, altitude on the one hand (Fig. 5a: $R=0.51$ ) and the distance from the coast on the other hand (Fig. 5b: $R=-0.23$ ).

\subsection{Connections between precipitation and GWL: anal- ysis for the wettest days of a rainy cold season (2000-2001)}

Western France and other areas in West-Central Europe (Berlamont, 1995; Drogue et al., 2006), were seriously affected by several hydrological crises in winter associated with remarkable wet periods since the early 1990s, especially in the cold season 2000-2001 and secondarily in 1993, 1995, $1997,2000,2001,2003$. While several authors (see the introduction of this paper) pointed up an increase of winter rainfall, connected to a higher frequency of westerlies over Europe and an increasing number of midlatitude cyclones over the North-West of Europe during the second half of the 20th century, the concomitant increase of daily precipitation intensity observed in winter in the British Isles over the last 40 years (Osborn and Hulme, 2002; Maraun et al., 2008) is a more complex feature at regional and local scales. The 


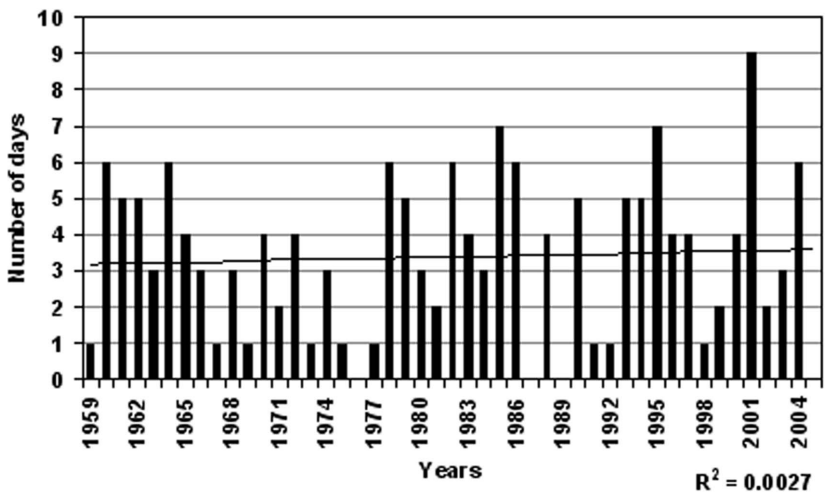

Fig. 6. Number of days with heavy precipitation $(\geq 20 \mathrm{~mm})$ at the weather station of Lorient by cold season (November-March) between 1958 and 2005.

number of days per cold season with precipitation $\geq 20 \mathrm{~mm}$ was calculated for the weather station of Lorient between 1958 and 2005, in order to show if the frequency of heavy rainfall events tends to increase from the mid-20th century too (Fig. 6).

Figure 6 shows a high interanual variability of the number of days with heavy precipitation, with no significant trend during the studied half-century $(R=0.052)$, but points up the cold season 2000-2001 with the highest number of days with heavy precipitation (9 days). Figure 6 shows two groups of remarkable cold seasons, during the 1980s and secondarily in the early 1960s, according to Maraun et al. (2008) in the United Kingdom. During the remarkable 2000-2001 cold season, 7 successive months with positive precipitation anomalies (based on the 1971-2000 average) were observed between October 2000 and April 2001, including two maxima: March 2001, $+178 \%$ and November 2000, $+149 \%$. All western France and adjacent areas were subjected to high positive precipitation anomalies, which caused severe floods (Marsh, 2001; Dupont et al., 2008).

The 2000-2001 cold season was characterized by a very high proportion of westerly and southerly circulations (69.5\%: Fig. 7a), but the southerly circulations were more frequent (51\% of all circulation types) than the westerly circulations $(18.5 \%)$. The high proportion of southerly circulations was essentially due to a high frequency of SWZ and TB circulation types $(63.6 \%$ of the southerly circulation types: Fig. 7b) and strongly affected the occurrence of daily precipitation (Fig. 7c and d).

During the period between November 2000 and March 2001, the precipitation proportion for both westerly and southerly circulation types was $80.5 \%$ of all GWL. According to the frequency of GWT (Fig. 7a), 59.6\% of precipitation was associated with the prevailing southerly circulations, while only $20.9 \%$ of precipitation was associated with westerly circulations (see Fig. 7b). The cyclonic south-westerly circulations (SWZ) was clearly the most frequent GWL for the cold season $2000-2001$ (43.7\% of all southerly circulation types and $26 \%$ of all circulation types: Fig. $7 d$ ). The meridional circulation associated with a low over the British Isles (TB) was the second most frequent cause of precipitation among the southerly circulations ( $14.2 \%$ of all GWL). Most of precipitation was due to the prevailing and long sequences of southerly circulation types between November and January, then March was characterized by heavy precipitation associated with north-westerly/northerly circulations (HNZ: $16.7 \%$ of all GWL; see Figs. 7d and 8). Between November and March 2000-2001, the very high precipitation proportion $(80.5 \%)$ associated with a lower proportion of southerly and westerly circulation types $(69.5 \%)$, weighted the precipitation proportion associated with these circulation types, while the importance of the precipitation associated with the other circulation types is lowered (circulation proportion: $30.5 \%$; precipitation proportion: $19.5 \%$ ).

The nine daily rainfall $\geq 20 \mathrm{~mm}$ recorded at Lorient during the remarkably wet 2000-2001 cold season were mostly associated with southerly circulations, and more precisely with the following GWLs: Anticyclonic South-Westerly (SWA: 1 day), Cyclonic South-Westerly (SWZ: 3 days), Anticyclonic Southerly (SA: 1 day), Low over the British Isles (TB: 2 days). The long (22 days) and rainy period of southerly circulation, which occurred during the three first weeks of November 2000 (total amount: $113.6 \mathrm{~mm}$ with two maxima: 11 November, $30.2 \mathrm{~mm}$ and 21 November, $24 \mathrm{~mm}$ ) was a succession of rain-producing weather patterns over the Atlantic western Europe (TB and TRW alternately), characterized by a surface low over the British Isles (TB) or a trough over Western Europe (TRW). These weather patterns are particularly heavy rain-producing in Western France (Planchon, 2005). The longest period of heavy rain (between November 2000 and early January 2001) was characterized by several sequences of Southerly (long duration) and Westerly (short duration) circulation types alternately. The heaviest rainfall event at Lorient was recorded on 31 December 2000 (SWZ: $41.8 \mathrm{~mm}$ ), the first day of a Cyclonic South-Westerly period.

The heavy rainfall events affecting Brittany during the wettest days of the 2000-2001 cold season (31 December 2000: SWZ; 11 November 2000: TB; 4 January 2001: SWZ; 19 March 2001: HNZ) were generated by large scale disturbed weather systems associated with a low located close to the British Isles (on 11 November 2000; 4 January 2001) or further westwards over the North Atlantic Ocean (on 31 December 2000; 19 March 2001), but the two highest daily rainfall amounts (on 31 December 2000; 4 January 2001) were associated with a Cyclonic South-Westerly circulation type. As shown by Moron (1990), the meridional circulations with a low located over the British Isles (TB circulation type e.g. on 11 November 2000) can be similar to a SW circulation (e.g. SWZ circulation type on 31 December 2000: Fig. 9), with a prevailing disturbances track over the northwestern part of Europe, and have the same heavy rain-producing effects in Western Europe including western France. 

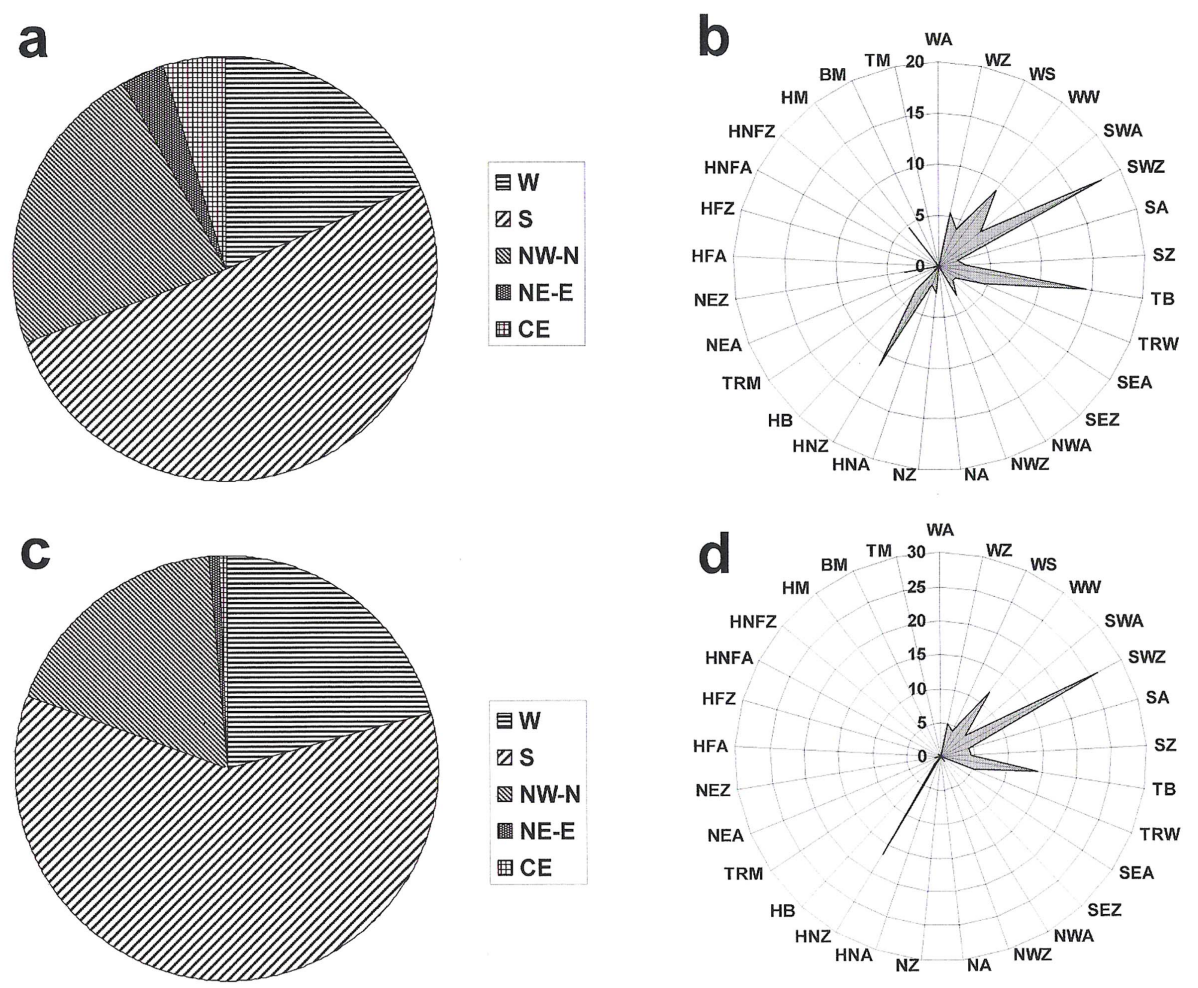

Fig. 7. Proportion of the Hess-Brezowsky GWT (a) and GWL (b) and proportion of precipitation by Hess-Brezowsky GWT (c) and GWL (d) at the weather station of Lorient (November 2000-March 2001). Legend to panels (a) and (c) (list of GWT): W: westerly circulation types, $\mathrm{S}$ : southerly circulation types, NW-N: northwesterly and northerly circulation types, NE-E: northeasterly and easterly circulation types, CE: main high/low pressure area over Central Europe. Legend to panels (b) and (d) (list of GWL): see Appendix A.

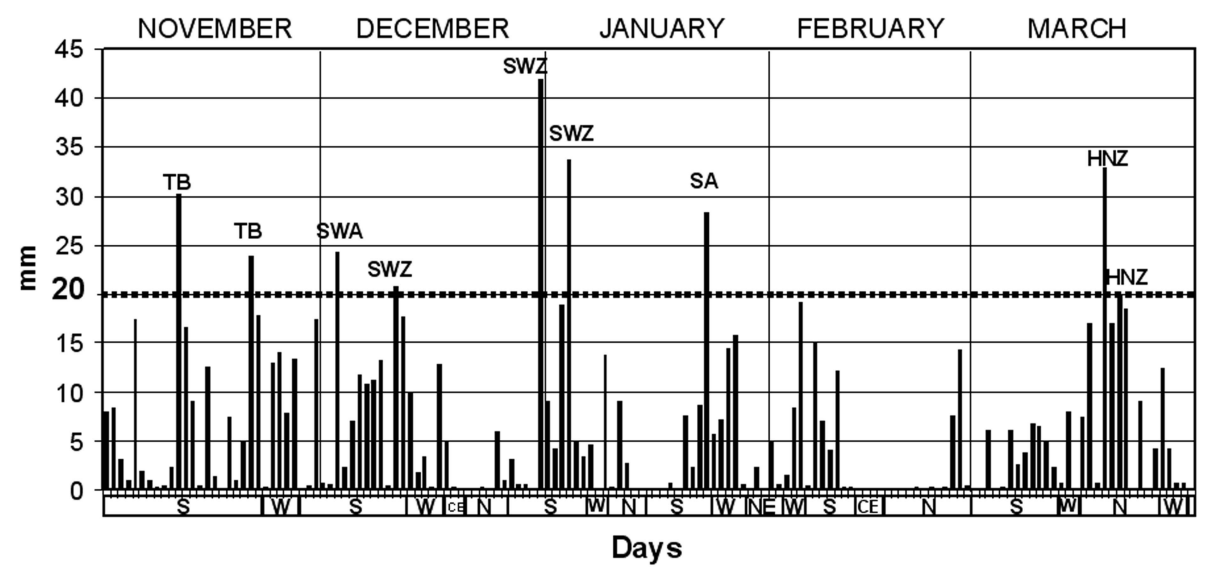

Fig. 8. Daily rainfall at Lorient (vertical bars) and Hess-Brezowsky GWT (horizontal bar) during the 2000-2001 cold season. GWLs are mentioned above each rainfall event $\geq 20 \mathrm{~mm}$.

Figure 10 suggests that the topographical effect, which causes a difference in the precipitation amounts between Lorient and the inland stations, could be enhanced or weakened depending on the prevailing rain-producing circulation types.

The comparison between the daily rainfall $\geq 10 \mathrm{~mm}$ for the 2000-2001 cold season at the three reference stations located in the Scorff catchment (Lorient, Plouay and Plouray) shows that the coastal station (Lorient) was clearly less rainy than the other two (inland) stations.

Topographical effects in hilly terrain cause higher rainfall amounts at the inland stations. The difference between the rainfall amounts of the coastal and inland stations was clearly shown during the wettest days $(\geq 20 \mathrm{~mm})$, e.g. the event of 31 December 2000: the stations of Lorient, Plouay 
a
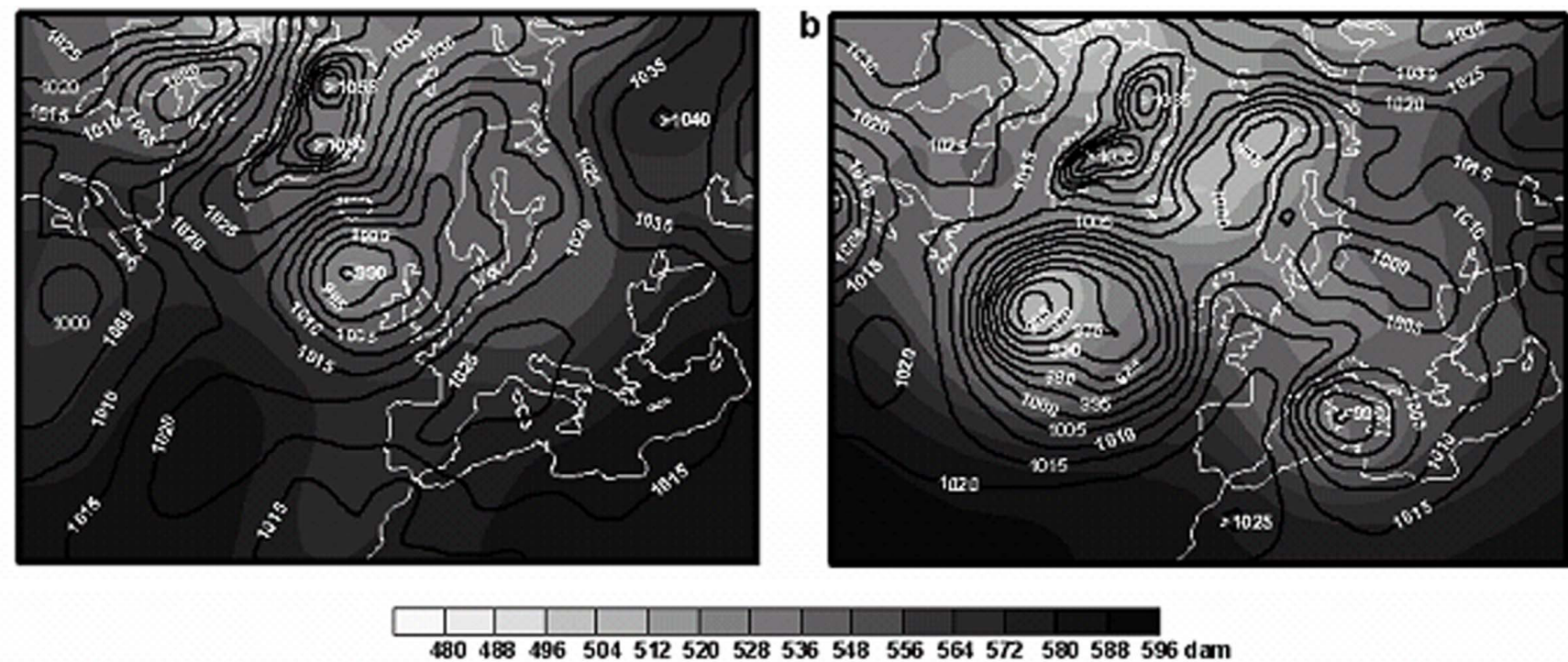

Fig. 9. Surface and high level maps (North Atlantic Ocean and Europe): sea level pressure (hPa) and geopotential at $500 \mathrm{hPa}$ level (dam) of weather situations producing high daily rainfall amounts during the 2000-2001 cold season. Adapted from NCEP Reanalysis, http: //www.wetterzentrale.de. (a) on 11 November 2000 (TB); (b) 31 December 2000 (SWZ).

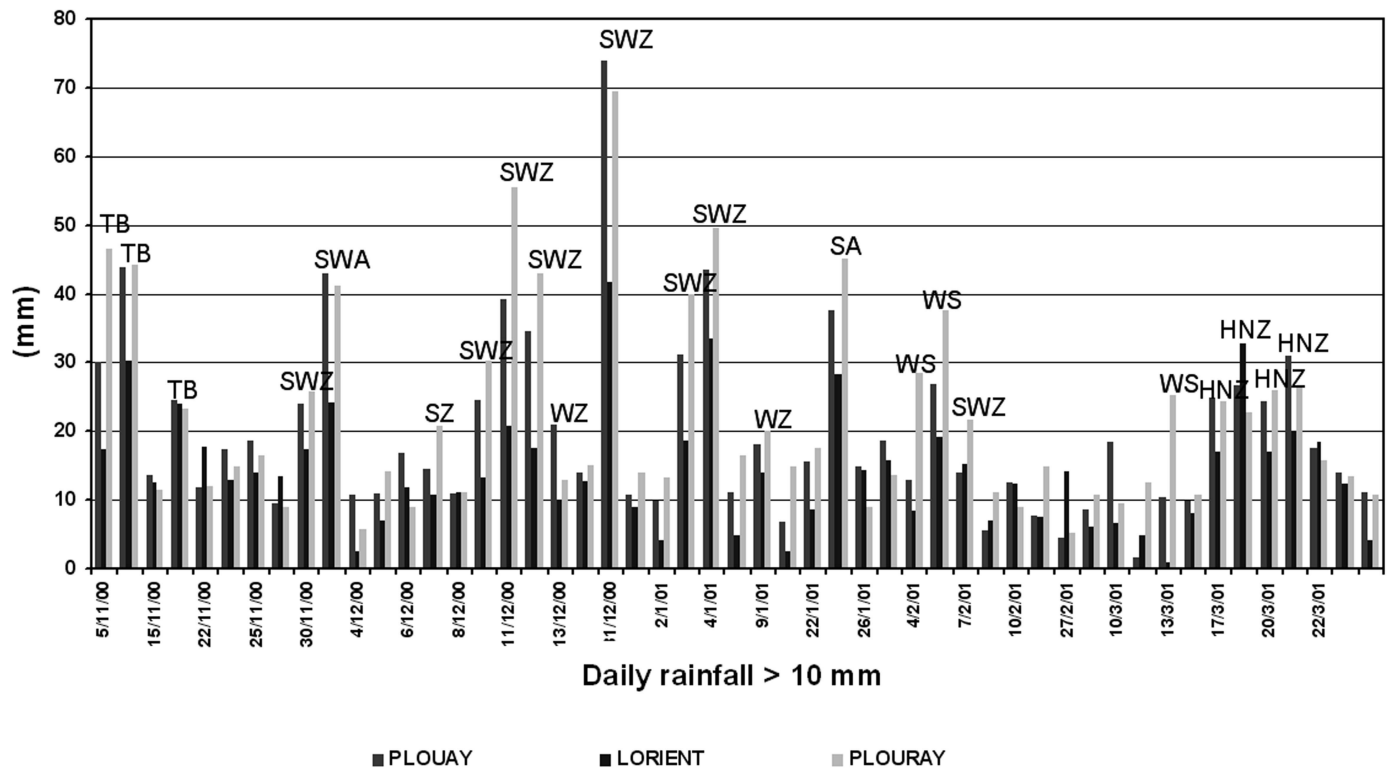

Fig. 10. Daily rainfall $\geq 10 \mathrm{~mm}$ at Plouay, Plouray and Lorient (vertical bars) and Hess-Brezowsky circulation types (GWL) corresponding to heavy rainfall ( $\geq 20 \mathrm{~mm}$ ) during the 2000-2001 cold season.

and Plouray recorded $41.8 \mathrm{~mm}, 74.1 \mathrm{~mm}$ and $69.6 \mathrm{~mm}$ respectively. Because of its inland location and its elevation ( $205 \mathrm{~m}$; a high alttitude in Brittany), the weather station of Plouray is most frequently the rainiest station. Plouray is located close to the southern slope of the Black Mountains, which reach about $300 \mathrm{~m}$ on the north-western edge of the Scorff catchment. Therefore, the precipitation amounts at the station of Plouray are enhanced by the combination between the topography (hilly terrain) and its exposure to the southwest quadrant, as shown by Svensson and Jones (2004) in small coastal watersheds in south and west Britain. Because of its sub-coastal location and its flat topographical environment, the weather station of Lorient is clearly less rainy than the two other stations during the days $\geq 20 \mathrm{~mm}$. These heavy rainfall events were mostly associated with Southerly circulation types, therefore the southern or south-western exposure of the catchment enhances heavy rainfall in the hilly inland area. 


\section{Conclusion}

The results shown in this paper point out the relevance of the Hess-Brezowsky classification of air circulation patterns in the identification of weather patterns producing significant winter precipitation in Brittany. The rain-producing effect of the westerly and southerly circulation types over all Brittany explains small spatial differences in precipitation proportion, but stations located in hilly areas facing west or south clearly record the highest proportion of daily precipitation $\geq 20 \mathrm{~mm}$ associated with westerly and southerly (especially cyclonic) circulation types. The most frequent occurrence of rainy days associated with westerly and southerly GWLs confirm well-known observations in western Europe and so justify the use of the Hess-Brezowsky classification in other areas outside Central Europe. The Hess-Brezowsky classification precisely allows to identify the rainy-air circulation patterns in western France and is therefore a useful tool to classify the rainfall events. The remarkably wet 2000-2001 cold season was characterized by a high rainfall spatial variability between the three selected stations of the Scorff watershed. Observations and analysis using the Hess-Brezowsky classification of circulation patterns confirm that the rainfall circulation types in the Scorff watershed during winter are characterized by surface flows blowing from the southwest quadrant. Because of the watershed exposure, the precipitation due to the high occurrence of SW circulation types during the 2000-2001 winter was enhanced at the inland stations.

The Hess-Brezowsky classification precisely allows to identify the rainy air-circulation patterns in western France and is therefore a useful tool to classify the rainfall events. The interannual variability of the frequency of GWT and GWL and its impact on the proportion of heavy precipitation for the last century will be examined in further studies, in relation with the question of a possible increasing winter precipitation intensity (Maraun et al., 2008). Thus, studies of rainy air-circulation patterns since 1850 will allow to point up trends and identify their possible connection with the climate change. Furthermore, a typology of the rainy winters depending on the occurrence of the circulation patterns and their effects on the spatial distribution of rainfall can be proposed and developed, taking connections with hydrological processes (floods) into account. Climatologists and hydrologists have long been aware of the relationship between climate and river flow (Kingston et al., 2006), but the HessBrezowsky classification was rarely used for studied connection between the climatic variability and stream flow (Stahl et al., 2002). Further studies will propose a typology of floods connected to the classified weather patterns using ObjectiveGWL system. These studies may allow to analyze the possible impacts of climate change on hydrological risks.

\section{Appendix A}

List of Hess-Brezowsky Major Types (GWT) and Subtypes (GWT) of circulation patterns (Fallot, 2000; Gerstengarbe and Werner, 2005; James, 2007).

\begin{tabular}{lc}
\hline Hess-Brezowsky Major Types (GWT) and & GWL \\
Subtypes (GWL) & \\
\hline Westerly circulations & \\
\hline Anticyclonic Westerly & WA \\
Cyclonic Westerly & WZ \\
South-Shifted Westerly & WS \\
Maritime Westerly (Block E. Europe) & WW \\
\hline Southerly circulations & \\
\hline Anticyclonic South-Westerly & SWA \\
Cyclonic South-Westerly & SWZ \\
Anticyclonic Southerly & SA \\
Cyclonic Southerly & SZ \\
Low over the British Isles & TB \\
Trough over Western Europe & TRW \\
Anticyclonic South-Easterly & SEA \\
Cyclonic South-Easterly & SEZ \\
\hline Northwesterly and northerly circulations & \\
\hline Anticyclonic North-Westerly & NWA \\
Cyclonic North-Westerly & HW \\
Anticyclonic Northerly & BM \\
Cyclonic Northerly & NA \\
Icelandic high, Ridge over Central Europe & NZ \\
Icelandic high, Trough over Central Europe & HNZ \\
High over the British Isles & HB \\
Trough over Central Europe & TRM \\
\hline Northeasterly and easterly circulations & \\
\hline Anticyclonic North-Easterly & NEA \\
Cyclonic North-Easterly & NEZ \\
Scandinavian High, Ridge over Central Eu- & HFA \\
rope & \\
Scandinavian High, Trough over Central Eu- & HFZ \\
rope & \\
High over Scandinavia-Iceland, Ridge over & HNFA \\
Central Europe & \\
High over Scandinavia-Iceland, Trough over & HNFZ \\
Central Europe & \\
\hline Main high/low pressure area over Central Europe \\
\hline High over Central Europe & \\
\hline & \\
\hline
\end{tabular}


Acknowledgements. The authors thank Paul James for giving them its own version of the Objective-GWL file.

Edited by: M.-C. Llasat

Reviewed by: three anonymous referees

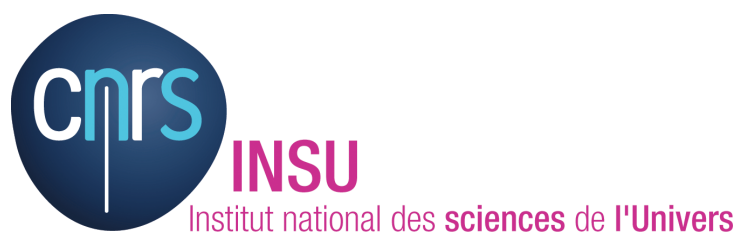

The publication of this article is financed by CNRS-INSU.

\section{References}

Bárdossy, A. and Caspary, H. J.: Detection of climate change in Europe by analysing European atmospheric circulation patterns from 1881 to 1989, Theor. Appl. Climatol., 42, 155-167, 1990.

Barry, R. G. and Chorley, R. J.: Atmosphere, weather and climate, Methuen, London, 460 pp., 1987.

Barrow, E. and Hulme, M.: Describing the surface climate of the British Isles, in: Climates of the British isles - past, present and future, edited by: Hulme, M. and Barrow, E., Routledge, London (UK), 33-62, 1997.

Bartholy, J., Pongrácz, R., and Pattanyús-Ábrahám, M.: European cyclone track analysis based on ECMWF ERA-40 data sets, Int. J. Climatol., 26, 1517-1527, 2006.

Berlamont, J. E.: Extreme floods in "the heart of Europe": the case of the 1995 Meuse flood, US-Italy Research Workshop on the Hydrometeorology, Impacts, and Management of Extreme Floods, Perugia (Italy), 6 pp., 1995.

Blanchet, G.: Régimes météorologiques et précipitations dans la région Rhône-Alpes, Recherches Géographiques à Strasbourg, 13-14(11-18), 1981.

Carluer, N. and De Marsily, G.: Assessment and modelling of the influence of man-made networks on the hydrology of a small watershed: implications for fast flow components, water quality and landscape management, J. Hydrol., 285, 76-95, 2004.

Cheverry, C.: Agriculture intensive et qualité des eaux, INRA Ed., Versailles, 298 pp., 1998.

Claval, F.: Les températures et les pluies en Franche-Comté, Revue Géographique de l'Est, 12(2-3), 297-304, 1972.

Contat, H., Lenoir, G., and Striffling, M.: Note sur les précipitations tombées en Bourgogne le 30 septembre 1965, La Météorologie, 4e série, 79, 259-265, 1965.

Corgne, S., Hubert-Moy, L., Barbier, J., Mercier, G., and Solaiman, B.: Follow-up and modelling of the land use in an intensive agricultural watershed in France, 9th International Symposium on Remote Sensing, Greece, 23-27 September 2002, Proceedings of SPIE, 4879: Remote Sensing for Agriculture, Ecosystems, and Hydrology IV, 342-351, 2002.

Corgne, S., Quénol, H., Planchon, O., and Corpetti, T.: Climate impact on the winter land use and land cover management in Brittany, in: Spatial Interpolation for Climate Data, The use of GIS in climatology and meteorology, chap. 18, edited by: Dobesch, H., Dumolard, P., and Dyras, I., ISTE Ltd, London (UK), 227-241, 2007.
Drogue, G., Wagner, C., and Pfister, L.: Quantification spatiale du changement de régime pluviométrique hivernal dans le bassin Rhin-Meuse, Actes du XIX ${ }^{\mathrm{e}}$ colloque de l'Association Internationale de Climatologie, Epernay (France), 202-207, 2006.

Dubreuil, V., Lejeune, C., and Mounier, J.: Changements climatiques régionaux dans la France de l'Ouest, Publications de l'Association Internationale de Climatologie, 9, 437-445, 1996.

Dupont, N., Dubreuil, V., and Planchon, O.: L'évolution récente des crues de la Vilaine : rôle des précipitations et de l'occupation du sol sur le bassin-versant, Publications de l'Association Internationale de climatologie, 13, 91-99, 2000.

Dupont, N., Planchon, O., Cador, J.M., Delahaye, D., and Douvinet, J.: Types de circulations atmosphériques et de crises hydrologiques dans le nord-ouest de la France : approches croisées de risques liés au climat, in: Climat et Risques: changements d'approches, edited by: Lamarre, D., Collection SRD, Lavoisier Ed., Paris, chap. 5, 63-92, 2008.

European Environment Agency: Impacts of Europe's changing climate, EEA Report Nr. 4, http://reports.eea.europa.eu/eea_report 2008_4/en/, 246 pp., 2008.

Fallot, J. M.: Evolution du nombre de jours avec des précipitations abondantes en Suisse durant le $20^{\mathrm{e}}$ siècle, Publications de l'Association Internationale de Climatologie, 13, 100-109, 2000.

Gerstengarbe, F. W. and Werner, P. C.: Katalog der Grosswetterlagen Europas (1881-2004), PIK Report nr. 100, Potsdam-Institut für Klimafolgenforschung, 153 pp., 2005.

Hess, P. and Brezowsky, H.: Katalog der Grosswetterlagen Europas, Bibliothek des Deutschen Wetterdienstes in der US-Zone 33, 39 pp., 1952.

James, P. M.: An objective classification for Hess and Brezowsky Grosswetterlagen over Europe, Theor. Appl. Climatol., 88, 1742, 2007.

Kessler, J. and Chambraud, A.: La Météo de la France, edited by: Lattès, J. C., 312 pp., 1986.

Kiely, G.: Climate change in Ireland from precipitation and streamflow observations, Adv. Water Resour., 23, 141-151, 1999.

Kingston, D. G., Lawler, D. M., and McGregor, G. R.: Linkages between atmospheric circulation, climate and streamflow in the northern North Atlantic: research prospects, Prog. Phys. Geog., 30(2), 143-174, 2006.

Klaus, D.: Zirkulations- und Persistenzänderungen des Europäischen Wettergeschehens im Spiegel der Grosswetterlagenstatistik, Erdkunde, 47, 85-104, 1993.

Klein Tank, A. M. G., Wijngaard, J. B., Können, G. P., Böhm, R., Demaree, G., Gocheva, A., Mileta, M., Pashiardis, S., Hejkrlik, L., Kern-Hansen, C., Heino, R., Bessemoulin, P., MüllerWestermeier, G., Tzanakou, M., Szalai, S., Palsdottir, T., Fitzgerald, D., Rubin, S., Capaldo, M., Maugeri, M., Leitass, A., Bukantis, A., Aberfeld, R., Van Engelen, A. F. V., Forland, E., Mietus, M., Coelho, F., Mares, C., Razuvaev, V., Niekoplova, E., Cegnar, T., Lopez, J.A., Dahlström, B., Moberg, A., Kirchhofer, W., Ceylan, A., Pachaliuk, O., Alexander, L.V., and Petrovic, P.: Daily dataset of 20th-century surface air temperature and precipitation series for the European Climate Assessment, Int. J. Climatol., 22(12), 1441-1453, 2002.

Klein Tank, A. M. G. and Können, G. P.: Trends in indices of daily temperature and precipitation extremes in Europe, 1946-1999, J. Climate, 16, 3665-3680, 2003.

Kyselý, J. and Huth, R.: Changes in atmospheric circulation over 
Europe detected by objective and subjective methods, Theor. Appl. Climatol., 85, 19-36, 2006.

Lebourgeois, F., Piedallu, C., Cluzeau, C., Nédeltcheva, T., and Badeau, V.: Développement, spatialisation et validation d'indices bioclimatiques, ECOFOR congress "Typologie des stations: blocages et avancées", Paris, 25 pp., 2006.

Maraun, D., Osborn, T. J., and Gillett, N. P.: United Kingdom daily precipitation intensity: improve early data, error estimates and an update from 2000 to 2006, Int. J. Climatol., 28(6), 833-842, 2008.

Marsh, T. J.: The 2000/01 floods in the UK - a brief overview, Weather, 56, 343-345, 2001.

Mayes, J.: Spatial and temporal fluctuations of monthly rainfall in the British Isles and variations in the mid-latitude westerly circulation, Int. J. Climatol., 16, 585-596, 1996.

Moberg, A. and Jones, P. D.: Trends in indices for extremes in daily temperature and precipitation in Central and Western Europe, 1901-99, Int. J. Climatol., 25, 1149-1171, 2005.

Moron, V.: Contribution à l'étude de la variabilité climatique mensuelle en Europe, Mémoire de D.E.A. (unpublished), Université de Bourgogne, Dijon, 75 pp., 1990.

Moussa, R., Voltz, M., and Andrieux, P.: Effects of the spatial organization of agricultural management on the hydrological behaviour of a farmed catchment during flood events, Hydrol. Processes, 16, 393-412, 2001.

Osborn, T. and Hulme, M.: Evidence for trends in heavy rainfall events over the UK, Philos. Transactions, 360(1796), 13131325, 2002.

Pagney, P.: Climats et cours d'eau de France, Masson, Paris, 248 pp., 1988.
Planchon, O.: Les printemps pluvieux des années 1980: retour sur une particularité météorologique et climatique de la fin du vingtième siècle en Europe occidentale, Actes du 18e colloque de l'Association Internationale de Climatologie, Genova (Italy), 349-352, 2005.

Planchon, O. and Dupont, N.: Identification of spring weather patterns causing floods in the East of Brittany (France), Geophys. Res. Abstr., 10, 09846, 3 pp., 2008.

Planchon, O., Quénol, H., and Corgne, S.: Apport de la classification de Hess-Brezowsky pour la typologie des types de circulations pluviogènes hivernales en Bretagne occidentale, Actes du 21e colloque de l'Association Internationale de Climatologie, Montpellier (France), 527-532, 2008.

Quénol, H., Planchon, O., and Corgne, S.: Interest of the HessBrezowsky classification of circulation patterns in the analysis of rainy winters in Brittany (France), Geophys. Res. Abstr., 10, 01279, 2 pp., 2008.

Stahl, K., Hassler, B., and Demuth, S.: Scenarios assessing the influence of climate variability on drought in Europe, Proceedings of the Fourth International FRIEND Conference, Cape Town (South Africa), IAHS 274, 93-100, 2002.

Svensson, C. and Jones, D. A.: Dependence between sea surge, river flow and precipitation in south and west Britain, Hydrol. Earth Syst. Sci., 8, 973-992, 2004, http://www.hydrol-earth-syst-sci.net/8/973/2004/.

Trzpit, J. P.: Activité cyclonique et rythmes climatiques aux latitudes moyennes : l'exemple du domaine atlantique et des espaces bordiers, Norois, 97-98, 69-168, 1978.

Wallén, C. C.: Climates of northern and western Europe, World Survey of Climatology, 5, Elsevier Publishing Company, Amsterdam, 1-21, 1970.

Werner, P. C., Gerstengarbe, F. W., Fraedrich, K., and Oesterle, H.: Recent climate change in the North Atlantic European sector, Int. J. Climatol., 20, 463-471, 2000. 